\title{
Risk Analysis of Coastal Disaster of Semarang City, Indonesia
}

\author{
Sunaryo Sunaryo ${ }^{1 *}$, Ambariyanto Ambariyanto ${ }^{2,3}$, Denny Nugroho Sugianto ${ }^{2,3}$, Muhammad Helmi ${ }^{2,3}$, Awaluddin $^{2}$ \\ Halirin Kaimuddin ${ }^{3}$, Agus Indarjo ${ }^{2}$ \\ ${ }^{1}$ Marine and Fisheries Affairs Office of Semarang City, Jl.Pemuda 175 Semarang Indonesia 50139 \\ ${ }^{2}$ Faculty of Fisheries and Marine Science, Diponegoro University, Jl. Prof.Soedarto SH, TembalangCampus, Semarang, \\ Indonesia 50275 \\ ${ }^{3}$ Coastal Disaster Rehabilitation and Mitigation Center, Integrated Laboratory, Diponegoro University, Jl. Prof. H. Soedarto, \\ SH, Tembalang, Semarang. 50275
}

\begin{abstract}
Coastal areas are highly vulnerable to disasters, as they are affected by events occurring both on land and at sea. In the development of cities in these areas, information on vulnerability levels is needed as a consideration in determining policy. This study aims to identify potential vulnerability of Semarang city, and to investigate the potential of hazard and disaster risk levels of the city. The study was conducted in 17 villages in the northern coastal area of Semarang. The assessment approach used was score analys is to some variables, i.e geomorphology, erosion, coastal slope, waves and socio-economic aspects. The research showed that the highest level of coastal vulnerability in the Semarang city were at three villages i.e.Terboyo Kulon, Terboyo Wetan and Trimulyo with value of 4.5; while the lowest level were at the Maron beach, Marina beach and Tanah Mas with value of 2.8. The highest potential coastal hazard in the Semarang city were at two villages i.e. Tanjung Mas and Tambak Lorok with value of 4.5; and the lowest value were in the village of Randugarut, Karanganyar, Tugurejo, Marina beach and Tanah Mas with value of 1.25.The highest level of coastal risk in the Semarang city were in the Trimulyo village with value of 3.13; and the lowest level were in the Marina beach and Tanah mas with value of 1.32 .
\end{abstract}

\section{Introduction}

Climate change has slowly happening within long time period which hard to be avoided. It closely related to temperature rise and season sifts which have impact on various human livelihoods $[1,2]$ as well as biodiversity [3]. Based on the report of intergovernmental panel on climate change [4], it gives significant effect, since 1850 had been recorded 11 of the hottest temperature happened in the past 12 years. The increasing temperatures in the period of 1850-1899 to 2001-2005 was $0,76^{\circ} \mathrm{C}$. This incident has caused the sea water mass swell and sea level rise. The global mean sea level have increased about 1,8 $\mathrm{mm} /$ yearin between 1961 to 2003. The recorded sea level rise in the 20 century is about $0,17 \mathrm{~m}$ [4].

Semarang city is one of coastal city at the northern coast of Java island, which is directly influenced by ocean. This condition causes various components including ecosystem, community and socioeconomic to get the risk pressure from marine dynamics affected by climate change and classified as vulnerable.
Vulnerability is a function magnitude of change and impact as well as climate change variation [5].

Along with the cause of sea level rise as one indicator of climate change in coastal areas of Semarang city that achieve $0.8 \mathrm{~mm} /$ year and the mean land subsidence ranging from $6-19 \mathrm{~cm} /$ year[5], causing some coastal communities as well as agricultural areas, in which their social economy depend on the resources, are becoming increasingly unreliable. Land subsidence has been reported to influence vulnerability $[6,7]$. The study on the effects of sea level rise becomes very important to understand how these impacts influencing the coastal cities. The impact of climate change through sea level rise has a tendency for coastal areas will be flooded, consequently, the coastal areas balance will also disturbed.

In this regard, this research attempts to identify potential risk and vulnerability of coastal area due to climate change impact; to assess potential hazard level and to assess disaster level on the coastal areas based on its' potential risk level.

* Corresponding author: $\underline{\text { sunaryosuling } @ \text { gmail.com }}$ 


\section{Research method}

The quantitative research method was used by undertaking scoring analysis on the specific research objects to get the real image of mapping pattern with different risk level on the coastal city of Semarang. Observation strategy (grand tour) and grouping strategy were applied to achieve the research objectives. Grand tour strategy was conducted to recognize the research areas, observation process was developed as an effort to search risk phenomena of coastal disaster. In addition, observation was also used to support grouping strategy in accordance to the characteristic of coastal areas.

Primary data were collected by interviewing respondent of fishermen and farmers, field observation and documentation; whereas secondary data collected from related institutions, such asthe Fisheries and Marine Board of Semarang city, the Board of Meteorology, Climatology dan Geophysics, Statistic Centerboards of Central Java Province, Development Planning Agency - Bappeda, and Office of Public Work - DPU. Data from 17 stations at Semarang coastal areas were collected both primary and secondary data. Disaster potential, coastal vulnerability and risk analysis were done based on collected data.

\subsection{Analysis of disaster potential}

Coastal disaster potential was determined using scoring model (see Table 1).

\subsection{Analysis of coastal vulnerabilitylevel}

Coastal vulnerability level was determined using scoring model based on the guide of disaster potential area analysis and climate change from the Ministry for Environment of New Zealand [8] (see Table 2).

The formula of coastal vulnerability as follows:

$\bar{K}=\frac{(S 1+S 2+S 3+S 4+S 5+S 6+I+E)}{8}$

$\bar{K}=$ coastal vulnerability value

\subsection{Analysis of risk potential}

Risk potential was calculated by using guide of coastal vulnerability level toward sea level rise [1] using formula:

$$
\text { Risk }=\frac{\sqrt{\text { disaster potential } \mathrm{x} \text { Coastal vulnerability }}}{2}
$$

The risk potential value of the research areas is classified as follows:
a. Low level : $0,1-0,7$
b. Medium level : $0,8-1,4$
c. High level : 1,5-2,1

Table 1. Scoring of Coastal Disaster Potential Level

\begin{tabular}{|l|c|c|c|c|c|}
\hline \multicolumn{1}{|c|}{ Variable } & Very low & Low & Medium & High & Very high \\
\cline { 2 - 5 } & $\mathbf{1}$ & $\mathbf{2}$ & $\mathbf{3}$ & $\mathbf{4}$ \\
\hline Geomorphology & Rocky shore & $\begin{array}{c}\text { Stepping } \\
\text { coast }\end{array}$ & $\begin{array}{c}\text { Low lying } \\
\text { coast, alluvial } \\
\text { land }\end{array}$ & $\begin{array}{c}\text { Estuary, } \\
\text { laguna, beach }\end{array}$ & $\begin{array}{c}\text { Sandy beach, bay } \\
\text { muddy beach, swamp, } \\
\text { delta, mangrove, coral } \\
\text { reefs }\end{array}$ \\
\hline $\begin{array}{l}\text { Coast line erosion/accretion } \\
\text { (m/year) }\end{array}$ & $>2.0$ & $1.0-2.0$ & $-1.0-1.0$ & $-2.0-1.0$ & $<-2.0$ \\
\hline Coastal slope $(\%)$ & $>1.9$ & $1.9-1.3$ & $1.3-0.9$ & $0.9-0.6$ & $<0.6$ \\
\hline Sea level rise $(\mathrm{mm} /$ year) & $<1.8$ & $1.8-2.5$ & $2.5-3.0$ & $3.0-3.4$ & $>3.4$ \\
\hline Mean wave high (m) & $<1.1$ & $1.1-2.0$ & $2.0-2.25$ & $2.25-2.6$ & $>2.6$ \\
\hline Mean tidal high $(\mathrm{m})$ & $>6.0$ & $4.0-6.0$ & $2.0-4.0$ & $1.0-2.0$ & $<1.0$ \\
\hline
\end{tabular}

Table 2. Coastal Vulnerability Level

\begin{tabular}{|c|c|c|c|c|c|}
\hline \multirow{3}{*}{$\begin{array}{l}\text { Acceptance } \\
\text { Compliant }\end{array}$} & \multicolumn{5}{|c|}{ Impacts } \\
\hline & Insignificant & Low & Medium & Significant & High \\
\hline & 1 & 2 & 3 & 4 & 5 \\
\hline $\begin{array}{l}\text { Total hous ehold } \\
\text { migration - S1 }\end{array}$ & $\begin{array}{l}<10 \\
\text { (short term) }\end{array}$ & $\begin{array}{l}10-50 \\
\text { (couple days) }\end{array}$ & $\begin{array}{l}50-100 \\
\text { (weeks /year) }\end{array}$ & $\begin{array}{l}100-200 \\
(\text { destruct } \\
\text { housing } \\
\text { permanently) }\end{array}$ & $\begin{array}{l}>200 \\
\text { (massive destruction housing } \\
\text { permanently) }\end{array}$ \\
\hline $\begin{array}{l}\text { Resident (total } \\
\text { victim - S2 }\end{array}$ & $<5$ & $1-10$ & $10-25$ & $25-50$ & $>50$ \\
\hline $\begin{array}{l}\text { Resident (total } \\
\text { fatalistic) - S3 }\end{array}$ & 0 & 0 & 1 & $<5$ & $>5$ \\
\hline $\begin{array}{l}\text { Economy Impact } \\
- \text { S4 }\end{array}$ & $\begin{array}{l}\text { Very low } \\
\text { impact }\end{array}$ & $\begin{array}{l}\text { Medium } \\
\text { impact to } \\
\text { several }\end{array}$ & $\begin{array}{l}\text { Medium impact } \\
\text { to many } \\
\text { entrepreneur }\end{array}$ & $\begin{array}{l}\text { Big impact to } \\
\text { many individu } \\
\text { and several }\end{array}$ & $\begin{array}{l}\text { Very big impact to many } \\
\text { individu and entrepreneur } \\
\text { and/or local government }\end{array}$ \\
\hline
\end{tabular}




\begin{tabular}{|c|c|c|c|c|c|}
\hline \multirow{3}{*}{$\begin{array}{l}\text { Acceptance } \\
\text { Compliant }\end{array}$} & \multicolumn{5}{|c|}{ Impacts } \\
\hline & Insignificant & Low & Medium & Significant & High \\
\hline & 1 & 2 & 3 & 4 & 5 \\
\hline & & entrepreneur & & entrepreneur & \\
\hline $\begin{array}{l}\text { Important } \\
\text { services - S5 }\end{array}$ & short term & In a day & $\begin{array}{l}\text { For several day } \\
\text { - a week }\end{array}$ & Long term & $\begin{array}{l}\text { Long term impact to broader } \\
\text { services }\end{array}$ \\
\hline $\begin{array}{l}\text { Commercial } \\
\text { services - S6 }\end{array}$ & short term & In a day & $\begin{array}{l}\text { For several day } \\
\text { - a week }\end{array}$ & Long term & $\begin{array}{l}\text { Long term impact to broader } \\
\text { services }\end{array}$ \\
\hline Infrastructure - I & short term & In a day & $\begin{array}{l}\text { For several day } \\
\text { - a week }\end{array}$ & $\begin{array}{l}\text { Need } \\
\text { development } \\
\text { /restoration }\end{array}$ & $\begin{array}{l}\text { Important infrastructure need } \\
\text { development } \\
\text { /restoration/relocation }\end{array}$ \\
\hline Ecosystem $-\mathrm{E}$ & short term & $\begin{array}{l}\text { to some } \\
\text { natural } \\
\text { resources }\end{array}$ & $\begin{array}{l}\text { to several } \\
\text { natural } \\
\text { resources }\end{array}$ & $\begin{array}{l}\text { to several } \\
\text { natural } \\
\text { resources }\end{array}$ & to all natural resources \\
\hline
\end{tabular}

\section{Result}

Semarang as one of Indonesia big cities located at coastal area. Geographically, it lays at $06^{0} 50^{\prime}-7^{0} 10^{\prime \prime}$ LSand $109^{0} 35^{\prime}-110^{0} 50^{\prime}$ BT with area of $37,360.947$ ha[9] with coastline of $36.63 \mathrm{~km}[10]$.

The coastal area of Semarang has elevation of 0 $0.75 \mathrm{~m}$ SWL with dominant slope of $0-2 \%$ is about $92 \%$ within $43 \%$ of coastal areas. The area nearby the sea has same elevation to the sea level and therefore often inundated due to tide, land subsidence and sea level rise. Most of these areas are used as brackish ponds operating by the tidal phenomena.

Coastal abrasion and accretion occur on the north coast of Central Java. These two natural phenomena have change coast line in which coastal abration affects accretion in other area because of long shore current activities. The worst abration was found at Genuk sub- district while worst accretion was at West Semarang [11]. See Table 3.

Analysis of coastal vulnerability at 17 stations show that station $8,9,10,11,12$ and 13 have medium level with value of 2.8. While high level occurred at station 4,5 , and 6 with value of 3.6. Very high level were found at station of1, 2, 3, 14, 15, 16 and 17 with value of4.1 - 4.5.

Disaster potential level in coastal area of Semarang within 17 locations shown that the station of $7,8,9,10$, 11 and 12 has medium level with value of 2.8 , high level occurred in the station of 4, 5, 6 and 7 with value of 3.8 ; while the very high level occurred the station of1, 2, 3, 13, 14, 15, 16 and 17 with value of $4.2-4.6$.

Table 3. Abrasion and accretion inSemarang

\begin{tabular}{|c|l|r|r|c|}
\hline No & \multicolumn{1}{|c|}{ Sub-district } & Abration (ha) & Accretion (ha) & Alteration (ha) \\
\hline 1 & Genuk & 153.47 & 5.12 & 148.35 \\
\hline 2 & North Semarang & 15.32 & 46.43 & -31.11 \\
\hline 3 & West Semarang & 4.59 & 48.89 & -44.30 \\
\hline
\end{tabular}

Tabel 4. Alignment between vulnerability, hazard and risks Semarang coastal

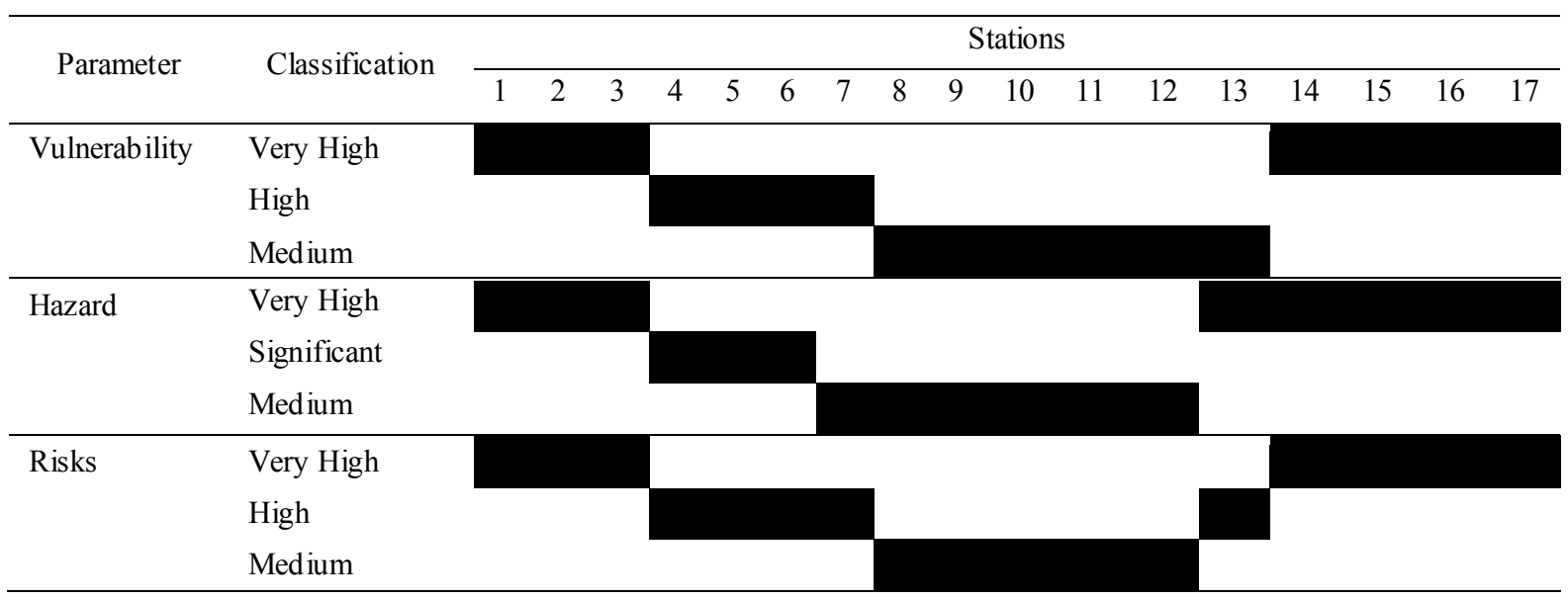


The results of the alignment analysis between vulnerability, hazards and risk indicate suitability in the study area and are correlative. Table 4 . The higher the vulnerability demonstrated high potential of hazard, which caused increase the level of risks. Furthermore, if assessed from the aspect or determinant components of this alignment then there is a variable that significantly influence it i.e. the wave.

\section{Discussion}

Coastal environment characterized by two different sites, the terrestrial which is static and the sea which is dynamic. The nature of cohesion between the two has eliciting a very specific condition [12]. Land is a contributor of material and energy to the marine ecosystems, subsequently the sea will assemble into a specific ecosystem. In addition, commonly there are three typical coastal ecosystems i.e. mangroves, sea grass beds and coral reefs. The next relations could be interpreted as reverse interaction, a place of processing land material to be a source of energy to the waters' environment, while those three ecosystems can be useful as a beach protection.

However cohesive relation between land and sea more often was suffering interruption from various factors. Antrophogenic factors regarded as a dominant factor that can cause disruption in between the two, which finally have impact against the static system of terrestrial [13]. The distractions are, for example, abrasion and accretion along the coast. There are some variables that related closely and by function become important factors, i.e. physical variables of tidal, elevation and slope, andsediment structure; social variables of population; and economic variables of land use [14].

When assessed of the environmental conditions of the study areas, the eastern and western regions of Semarang receive the load of energy from incoming wave. The amount of energy was different from one time to time in the annual period. Large load in eastern and western areas probably due in two ways, the first formed by natural and the next formed by artificially. By nature area of Mangunharjo region, Mangkang Wetan and Randugarut as the representation of aside point 1, 2 and 3 (S1, S2 and S3) in the west, while Tambak Lorok, Terboyo Kulon and Terboyo Wetan and Trimulyo as the representation of sampling points 14 (S- 14), S-15, S-16 and S-17 in the eastern region more developed towards the north compared with the S-4 to S-13 which are the representation of middle area. Furthermore, the middle region (ranging from Karanganyar, tapak, TugurejoMaron Beach, Coastal Marina to Tambakrejo) has changed considerably by land conversion and has relatively lower from the pressure wave.

Another impact is tide which cause increased of rob (water inundation) at Semarang coastal areas. This event is worsenby land subsidence. The rate of land subsidence in Semarang in general higher towards to the northern area, since the conditions in Semarang southern region is highland. It is also influenced by the type of soil in the coastal area which is young soft soil layers so they are still continue to compression/ consolidation. Furthermore, Semarang coastal area is very dense with industrial activities, building construction, reclamation, hoarding land and groundwater extraction which accelerates the rate of soil degradation. Land subsidence caused by groundwater for residential, and industrial, building increasing load, groundwater is increasing from year to year. Indications even this have of synergism with the pattern of use of space along the coastal Semarang.

Accumulative influence of wave, tidal and land subsidence is a determining factor to the increasing flood of in Semarang. Observations estimated that the increase in sea level a result of increasing temperature was around $1 \mathrm{~mm} /$ year in the last decade. Deep sea waves are generally no direct effect on coastal area, while near the coast waves, especially in the area of the surf (surf zone) has a great energy which influence the formation of coastal morphology like a drag sediment (sediment-sized sand and gravel) are located on the seabed transported and dumped in the form sandbars (sand bar) [15]. Some reports show the influence of sediment and waves on the coastal line $[16,17]$.

Based on this fact and when linked with land use along the coast Semarang indicate that sedimentation potentially occur in areas in the western region (representation S-1 to S-4) and the eastern region (representation S-13 and S-17).The effects associated with it was the high abrasion. Factors that increase the influence of waves on the shore abrasion can occur with increasing accumulation with the high tides [12]. This indication appears in the areas of development, especially in the eastern region of Semarang, where its influence is very strong in the region of Sayung. This condition has been aggravated by the development of inland ponds and thinness a mangrove forest, which cause flood in the eastern region.

Therefore, the land management along the coastal area of Semarang indicates potential risk from the west to the east. The impact of this regard is, for example, high abrasion in Genuk region approximately153.47 ha. Waves could increase abrasion on the beach and occur synergistically in accumulation of the tide [12]. This indication happened on the development areas, particularly in Sayung. This condition is worsen by brackish water ponds as well as decreasing mangrove areas that enlarge inundation areas in the eastern part of Semarang city.

\section{Conclusion}

The highest vulnerability level at Semarang city are in the villages of Terboyo Kulon, Terboyo Wetan and Trimulyo with value of 4.5; while the lowest level are in the Maron beach, Marina beach and Tanah Mas with value of 2.8. The highest potential coastal danger in the Semarang city were at the Tanjung Mas and TambakLorok with value of 4.5 ; and the lowest value were in the village of Randugarut, Karanganyar, 
Tugurejo, Marina beach and Tanah Mas with value of 1.25.The highest level of coastal risk in the Semarang city were in the Trimulyo village with value of 3.13 ; and the lowest level were in the Marina beach and Tanah mas with value of 1.32 .

\section{References}

1. S. Diposaptono, Budiman, Agung, F. Penerbit Buku Ilmiah Populer, Bogor,359 pp. (2009)

2. O. Hoegh-Guldberg, H. Hoegh-Guldberg, Veron, J.E.N., A. Green, E. D. Gomez, J. Lough, M. King, A. Ambariyanto, L. Hansen, J. Cinner, G. Dews, G. Russ, H. Z. Schuttenberg, E.L. Peñaflor, C. M. Eakin, T. R. L. Christensen, M. Abbey, F. Areki, R. A. Kosaka, A. Tewfik, J. Oliver, WWF Australia. (2009)

a. Ambariyanto, In IOP Conference Series: Earth and Environmental Science, 55, 1: 012002. IOP Publishing. (2017)

3. IPCC.In:Solomon, S., D. Qin, M. Manning, Z. Chen, M. Marquis, K.B. Averyt, M.Tignor and H.L. Miller (eds.). Cambridge University Press, Cambridge, United Kingdom and New York, USA.(2007)

4. H.M. Füssel, and R.J. Klein, Climatic change, 75,3:301-329 (2006)
5. P.L.A. Wibowo, A. Hartoko, and A. Ambariyanto Ilmu Kelautan, 20,3:127-134 (2015)

6. H.Z. Abidin, H. Andreas, I. Gumilar, T.P. Sidiq, and Y. Fukuda, Geomatics, Natural Hazards and Risk, 4,3: 226-240(2013)

7. Ministry for Environment - New Zealand Government. (2008)

8. BPS Kota Semarang. Balai Pusat Statistik Kota Semarang. (2015)

9. DKP. Laporan Dinas Kelautan dan Perikanan, Kota Semarang. (2010)

10. DKP. Laporan Dinas Kelautan dan Perikanan, KotaSemarang. (2011)

11. A.S. Trenhaile, Clarendon Press, Oxford, United Kingdom,366 pp (1997)

12. R.J. Nicholls, and J. Branson.Geographical Journal, 164,3:255-258 (1998)

13. G. Ozyurt, and A. Ergin. Journal of Coastal Research. Lisbon Portugal. (2009)

14. R. Dahuri, J.Rais, S.P.Ginting and M.J. Sitepu. PT. Pradnya Paramita,Jakarta.(1996)

15. Rifardi, R. Ilmu Kelautan. 13, 3: 147-152 (2010)

16. Rositasari, R.Ilmu Kelautan. 12, 3:146-156(2007)

17. A.D. Siswanto, W.A. Pratikto, and S., Suntoyo, Ilmu Kelautan 15, 4: 221-230(2012) 